\title{
Universiteit
}

Leiden

The Netherlands

\section{Interpreting the expansion of sea fishing in medieval Europe using stable isotope analysis of archaeological cod bones}

Barrett, J.H.; Orton, D.; Johnstone, C.; Harland, J.; Van Neer, W.; Ervynck, A.; ... ; Richards, M.

\section{Citation}

Barrett, J. H., Orton, D., Johnstone, C., Harland, J., Van Neer, W., Ervynck, A., ... Richards, M. (2011). Interpreting the expansion of sea fishing in medieval Europe using stable isotope analysis of archaeological cod bones. Journal Of Archaeological Science, 38(7), 1516-1524. doi:10.1016/j.jas.2011.02.017

Version: Publisher's Version

License: $\quad$ Leiden University Non-exclusive license

Downloaded from: https://hdl.handle.net/1887/139181

Note: To cite this publication please use the final published version (if applicable). 


\title{
Interpreting the expansion of sea fishing in medieval Europe using stable isotope analysis of archaeological cod bones
}

\author{
James H. Barrett ${ }^{\mathrm{a}, *}$, David Orton ${ }^{\mathrm{a}}$, Cluny Johnstone ${ }^{\mathrm{b}}$, Jennifer Harland ${ }^{\mathrm{a}}$, Wim Van Neer ${ }^{\mathrm{c}, \mathrm{d}}$, \\ Anton Ervynck ${ }^{\mathrm{e}}$, Callum Roberts ${ }^{\mathrm{f}}$, Alison Locker $^{\mathrm{g}}$, Colin Amundsen ${ }^{\mathrm{h}}$, Inge Bødker Enghoff ${ }^{\mathrm{i}}$, \\ Sheila Hamilton-Dyer ${ }^{\mathrm{j}}$, Dirk Heinrich ${ }^{\mathrm{k}}$, Anne Karin Hufthammer ${ }^{1}$, Andrew K.G. Jones ${ }^{\mathrm{m}}$, Leif Jonsson ${ }^{\mathrm{n}}$, \\ Daniel Makowiecki ${ }^{\mathrm{o}}$, Peter Pope ${ }^{\mathrm{p}}$, Tamsin C. O'Connell ${ }^{\mathrm{a}, \mathrm{q}}$, Tessa de Roo ${ }^{\mathrm{q}}$, Michael Richards ${ }^{\mathrm{r}, \mathrm{s}}$
}

${ }^{a}$ McDonald Institute for Archaeological Research, University of Cambridge, Downing Street, Cambridge CB2 3ER, UK

b Department of Archaeology, University of York, The King's Manor, York Y01 7EP, UK

${ }^{\mathrm{c}}$ Royal Belgian Institute of Natural Sciences, Vautierstraat 29, B-1000 Brussels, Belgium

${ }^{\mathrm{d}}$ Katholieke Universiteit Leuven, Laboratory of Animal Biodiversity and Systematics, Ch. Debériotstraat 32, B-3000 Leuven, Belgium

e Flemish Heritage Institute, Koning Albert II-laan 19 box 5, B-1210 Brussels, Belgium

${ }^{\mathrm{f}}$ Environment Department, University of York, York YO10 5DD, UK

${ }^{\mathrm{g}}$ Edifici L'Ingla, Atic 1a, 58 Avenguda del Pessebre, Escaldes-Engordany, AD 700, Andorra

${ }^{\mathrm{h}}$ University of Tromsø, Department of Archaeology and Social Anthropology, HSL-Faculty, Tromsø 9036, Norway

${ }^{\mathrm{i}}$ Natural History Museum of Denmark (Zoological Museum), University of Copenhagen, Universitetsparken 15, DK-2100 Copenhagen $\emptyset$, Denmark

j 5 Suffolk Avenue, Shirley, Southampton, SO15 5EF, UK

${ }^{\mathrm{k}}$ Zoological Institute, Christian-Albrechts-Universität zu Kiel, Olshausenstraße 40, D-24118 Kiel, Germany

${ }^{1}$ Bergen Museum, Natural History Collections, University of Bergen, Postboks 7800, 5020 Bergen, Norway

${ }^{m}$ York Archaeological Trust, 47 Aldwark, York Y01 7BX, UK

${ }^{\mathrm{n}}$ Gothenburg Museum of Natural History, Box 7283, SE 40235 Gothenburg, Sweden

${ }^{\circ}$ Institute of Archaeology, Nicolaus Copernicus University, Szosa Bydgoska St. 44/48, PL 87-100 Toruń, Poland

${ }^{\mathrm{p}}$ Department of Archaeology, Memorial University of Newfoundland, St. John's, Newfoundland A1C 5S7, Canada

${ }^{\mathrm{q}}$ Department of Archaeology, University of Cambridge, Downing Street, Cambridge CB2 3DZ, UK

${ }^{\mathrm{r}}$ Department of Anthropology, University of British Columbia, 6303 NW Marine Drive, Vancouver, British Columbia V6T 1Z1, Canada

${ }^{\mathrm{s}}$ Department of Human Evolution, Max Planck Institute for Evolutionary Anthropology, Deutscher Platz 6, 04103 Leipzig, Germany

\section{A R T I C L E I N F O}

\section{Article history:}

Received 16 October 2010

Received in revised form

8 February 2011

Accepted 15 February 2011

\section{Keywords:}

Trade

Economic intensification

Urbanism

Stable isotopes

Cod

Middle ages

\begin{abstract}
A B S T R A C T
Archaeological fish bones reveal increases in marine fish utilisation in Northern and Western Europe beginning in the 10th and 11th centuries AD. We use stable isotope signatures from 300 archaeological cod (Gadus morhua) bones to determine whether this sea fishing revolution resulted from increased local fishing or the introduction of preserved fish transported from distant waters such as Arctic Norway, Iceland and/or the Northern Isles of Scotland (Orkney and Shetland). Results from 12 settlements in England and Flanders (Belgium) indicate that catches were initially local. Between the 9th and 12th centuries most bones represented fish from the southern North Sea. Conversely, by the 13th to 14th centuries demand was increasingly met through long distance transport - signalling the onset of the globalisation of commercial fisheries and suggesting that cities such as London quickly outgrew the capacity of local fish supplies.
\end{abstract}

(c) 2011 Elsevier Ltd. All rights reserved.

\section{Introduction}

The analysis of fish bones from archaeological sites indicates increases in marine fishing in Northern and Western Europe around the turn of the first and second millennia AD (Benecke,

\footnotetext{
* Corresponding author. Tel.: +44(0)1223339287; fax: +44(0)1223339285

E-mail address: jhb41@cam.ac.uk (J.H. Barrett).
}

1982; Barrett et al., 1999, 2004a; Enghoff, 1999, 2000; Ervynck et al., 2004; Jones, 1988; Lõugas, 2008; Makowiecki, 2008; Müldner, 2009). Past research has identified two alternative scenarios that might explain this change in the relationship between people and the sea - a transformation that started the globalisation of the world's fisheries and that has continued to the present (Barrett et al., 2004a; Hoffmann, 1996, 2002; Perdikaris and McGovern, 2008; Roberts, 2007). One possibility is that the 
medieval rise in sea fish utilisation resulted from a change in supply - the start of long-range trade in staple goods from the north-east Atlantic, Arctic Norway and the Baltic Sea to the urbanised southern North Sea littoral. A development of this kind could have been driven by the Viking Age Scandinavian diaspora (connecting producer and consumer regions in new networks), increased ship capacities (allowing more bulky cargoes) and the Medieval Warm Period (influencing the success of seafaring and the productivity of Arctic cod stocks). Alternatively, the medieval fishing revolution could have resulted from a demand-led intensification of local marine fishing - to meet new food requirements influenced by growing human populations, Christian fasting practises (fish were substituted for the meat of quadrupeds), the over-exploitation of freshwater fish stocks and the effects of human-induced habitat change on freshwater species. It is important to determine which of these alternative hypotheses is most probable. The resulting growth of intensive and/or extensive marine fishing has had profound social, economic and environmental impacts on both short and long timescales (Hoffmann, 2002; Jackson, 2008; Jackson et al., 2001; Rick and Erlandson, 2008; Roberts, 2007).

The written evidence regarding Europe's medieval fisheries is sporadic until the 14th century (Holm et al., 1996; Kowaleski, 2003; Starkey et al., 2009) - postdating the years during which, as demonstrated by archaeological evidence, large-scale sea fishing first developed (Barrett et al., 2004a). Thus to differentiate the alternative scenarios we ideally need a way to discover where the fish whose bones have been recovered from archaeological excavations were originally caught. At the very least it is essential to reconstruct when preserved sea fish were first transported over hundreds or thousands of kilometres, and what the relative magnitude of this long-range transport was in comparison with the produce of local marine fishing.

Having developed such a technique, based on stable carbon and nitrogen isotope analysis of fish bone collagen (Barrett et al., 2008), we apply it here to finds of cod (Gadus morhua) bones from London and 11 other urban centres and villages bordering the southern North Sea in England and Flanders (Belgium). Alternative methodologies exist for determining the origin of modern cod catches, but these require otoliths which rarely preserve in archaeological deposits, employ trace elements susceptible to contamination from the burial environment or use genetic markers which may have changed over time due to modern fishing pressure (Hutchinson et al., 2003; Pampoulie et al., 2008; Svedäng et al., 2010).

In addition to cod, the taxa most important in Europe's sea fishing revolution included herring (Clupea harengus), flatfish (Pleuronectidae), haddock (Melanogrammus aeglefinus) and other gadids (Gadidae). Of these, herring is the most consistently abundant find in the southern North Sea and Baltic regions (Barrett et al., 1999, 2004a; Enghoff, 1999, 2000; Ervynck et al., 2004; Jones, 1988; Lõugas, 2008; Makowiecki, 2008). However, cod is the best archaeological proxy for the study of long-range fish trade. This species is known to have been widely traded in the past (Starkey et al., 2009), has bones of an ideal size to extract sufficient purified collagen for analysis and (having large bones) can be recovered on archaeological sites even when sediment is not sieved. Crucially, it also has well-understood migration patterns, with many populations remaining close to their spawning grounds (Bagge et al., 1994; Deutsch and Berth, 2006; Holmes et al., 2008; Sarvas and Fevolden, 2005; Svedäng et al., 2007, 2010; Wright et al., 2006).

Our study is based on two steps, involving the stable isotope analysis of collagen from archaeological cranial (control) and postcranial (target) cod bones respectively. Cranial bones are likely to derive from relatively local catches because, prior to refrigeration, cod were typically decapitated and dried (with or without salting) for long-range transport or trade. Conversely, postcranial bones (specifically vertebrae and cleithra, the latter of which support the pectoral fins) were typically left in traditional fish products such as stockfish (air-dried cod) before transport to consumers (Barrett, 1997; Coy and Hamilton-Dyer, 2005). Thus target specimens could be from either local catches or long-range transport - and a comparison of the stable isotope values of control and target specimens can reveal the introduction of non-local catches (Barrett et al., 2008).

\section{Material and methods}

\subsection{Control and target samples}

Samples of archaeological cod cranial ( $n=208)$, and postcranial $(n=188)$ bones for $\delta^{13} \mathrm{C}$ and $\delta^{15} \mathrm{~N}$ analysis of collagen were obtained from over 50 archaeological assemblages from six analytical regions: Newfoundland, Arctic Norway, the north-east Atlantic (Iceland and northern Scotland), the southern North Sea (below $55^{\circ} \mathrm{N}$ ) and English Channel, the Kattegat/western Baltic Sea and the eastern Baltic Sea. Studies of cod migration patterns indicate limited natural movement between the designated regions (Bagge et al., 1994; Deutsch and Berth, 2006; Holmes et al., 2008; Sarvas and Fevolden, 2005; Svedäng et al., 2007, 2010; Wright et al., 2006). Where practicable, sampling regions were specifically defined based on the known existence of separate cod populations (e.g. the Kattegat/western Baltic versus the eastern Baltic) (Bagge et al., 1994; Deutsch and Berth, 2006). The regions considered include known fishing grounds exploited by Europeans in medieval and/or post-medieval times (Starkey et al., 2009).

Sample selection aimed at good geographical and temporal coverage of each region, but was constrained by standard archaeological contingencies of preservation and accessibility, exacerbated by variable laboratory success rates. 171 of the cranial specimens and 129 of the postcranial specimens were successful, producing high yields of collagen with acceptable atomic $\mathrm{C}: \mathrm{N}$ ratios (see Section 2.6). All except two of the target (postcranial) specimens, both from Wharram Percy in England (Barrett et al., 2008), are reported here for the first time. Data regarding a subset of 74 of the control (cranial) specimens was summarised previously in a pilot study (Barrett et al., 2008).

Outliers within the control (cranial) samples might reflect rare instances of fish imported without prior decapitation (Jonsson, 1986). Thus we excluded the single clearest outlier from each region, defined by the greatest mean of the $z$-scores for $\delta^{13} \mathrm{C}$ and $\delta^{15} \mathrm{~N}$. No outliers were excluded from the target data set.

\subsection{Size-based variability}

Since higher trophic levels in older, larger fish could result in elevated $\delta^{13} \mathrm{C}$ and $\delta{ }^{15} \mathrm{~N}$ values (DeNiro and Epstein, 1978; Jennings et al., 2002; Minagawa and Wada, 1984; Schoeninger and DeNiro, 1984), the archaeological samples were restricted to cod with estimated total lengths in the $500-1000 \mathrm{~mm}$ range (based on bone measurements and comparison with reference specimens of known size) (Barrett et al., 2008). Size effects were also mitigated by analysing complete bone cross-sections - providing approximate life-time averages given the incremental nature of fish bone growth (Van Neer et al., 1999). Comparison of $\delta^{13} \mathrm{C}$ and $\delta^{15} \mathrm{~N}$ values between smaller (500-800 mm) and larger (800-1000 mm) fish within each region using $t$-tests revealed only one significant difference, for $\delta^{15} \mathrm{~N}$ in Arctic Norway $(t=-2.11, \mathrm{df}=39, p=0.041)$ (see Fig. 1). In future research it may be possible to further control for trophic level effects using amino acid-specific stable isotope 

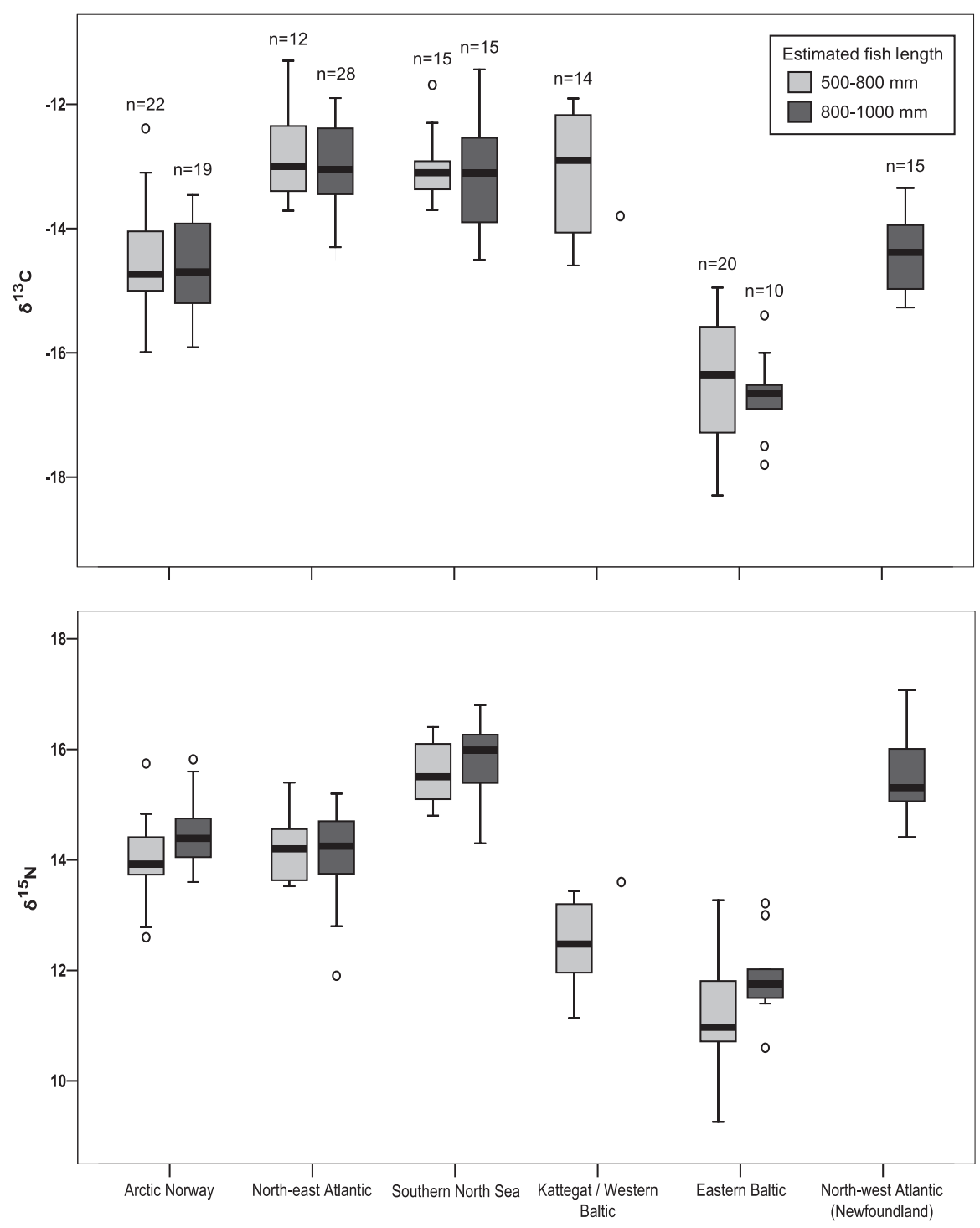

Fig. 1. Boxplots showing distributions of $\delta^{13} \mathrm{C}$ and $\delta^{15} \mathrm{~N}$ for smaller (500-800 mm total length) and larger (800-1000 mm total length) cod from the control groups, by region.

compositions (Hannides et al., 2009). The present demonstration of spatial patterning in collagen stable isotope values is, however, a necessary precursor to work of this kind.

\subsection{Temporal variability}

To address temporal variability in stable isotope signatures we did not include any archaeological samples of 19th-21st-century date that might have altered $\delta^{15} \mathrm{~N}$ values - due to radical changes in food webs and/or pollutants such as agricultural fertilisers and sewage (Christensen and Richardson, 2008; Doney, 2010; Hansson et al., 1997; Struck et al., 2000). The archaeological control samples of 9 th-18th century date were also classified into five two-century groups and compared within each region using boxplots (see Fig. 2) and ANOVA. Significant temporal differences in $\delta^{13} \mathrm{C}$ and $\delta^{15} \mathrm{~N}$ values were absent from all regions except the eastern Baltic, where there is a decrease in $\delta^{13} \mathrm{C}$ between the 13th to 14th and 15th to 16 th centuries $(\mathrm{F}(\mathrm{df} 1,28)=15.58, p<0.001)$. The magnitude of this effect is small relative to differences between regions, and the eastern Baltic remains clearly separated from other regions when $\delta^{13} \mathrm{C}$ and $\delta^{15} \mathrm{~N}$ are taken together (Fig. 3).

\subsection{Variability within regions}

Since the regions are large, treating them as single units may mask finer-scale geographic variation. However, ANOVA of the different settlements represented in each region produced only one significant result, for $\delta^{13} \mathrm{C}$ values from the eastern Baltic ( $\mathrm{F}(\mathrm{df} 2$, $27)=3.50, p=0.045)$. As for temporal variability, the eastern Baltic nevertheless remains clearly separated when $\delta^{13} \mathrm{C}$ and $\delta^{15} \mathrm{~N}$ are taken together (Fig. 3).

\subsection{Intra-skeletal variability}

To confirm that there is unlikely to be systematic intra-skeletal variability in the stable isotope signatures employed we analysed the $\delta^{13} \mathrm{C}$ and $\delta^{15} \mathrm{~N}$ of collagen extracted from one cranial bone (a praemaxilla) and two postcranial bones (a cleithrum and an anterior caudal vertebra) from each of eight cod caught in the North Sea in 1992. The individuals ranged from 460 to $950 \mathrm{~mm}$ in total length. There was no systematic difference in the isotope values between skeletal elements and all fish showed small intraindividual variability. The maximum ranges between skeletal 

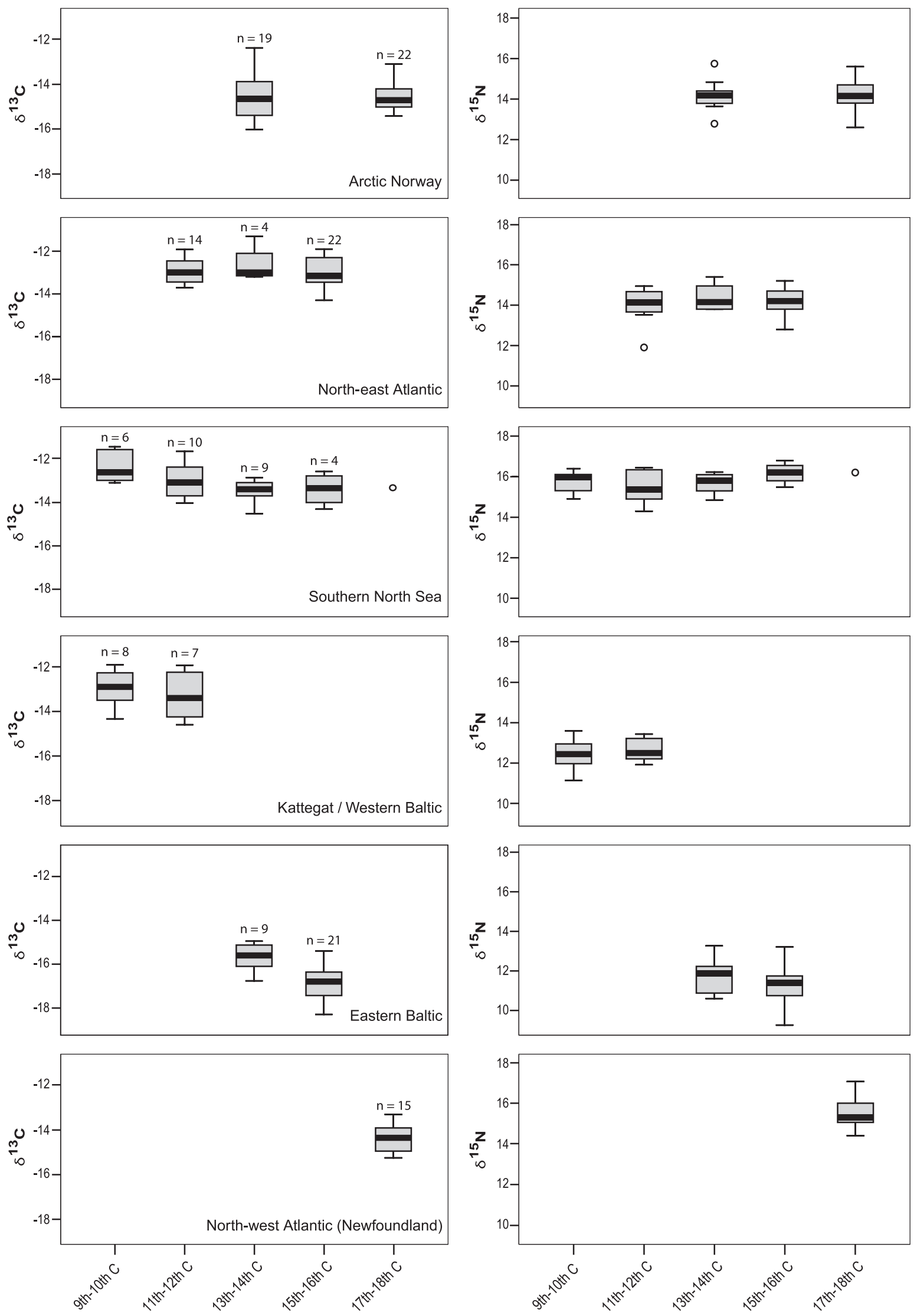

Fig. 2. Boxplots comparing distributions of $\delta^{13} \mathrm{C}$ and $\delta^{15} \mathrm{~N}$ over time within the control groups, by region. 


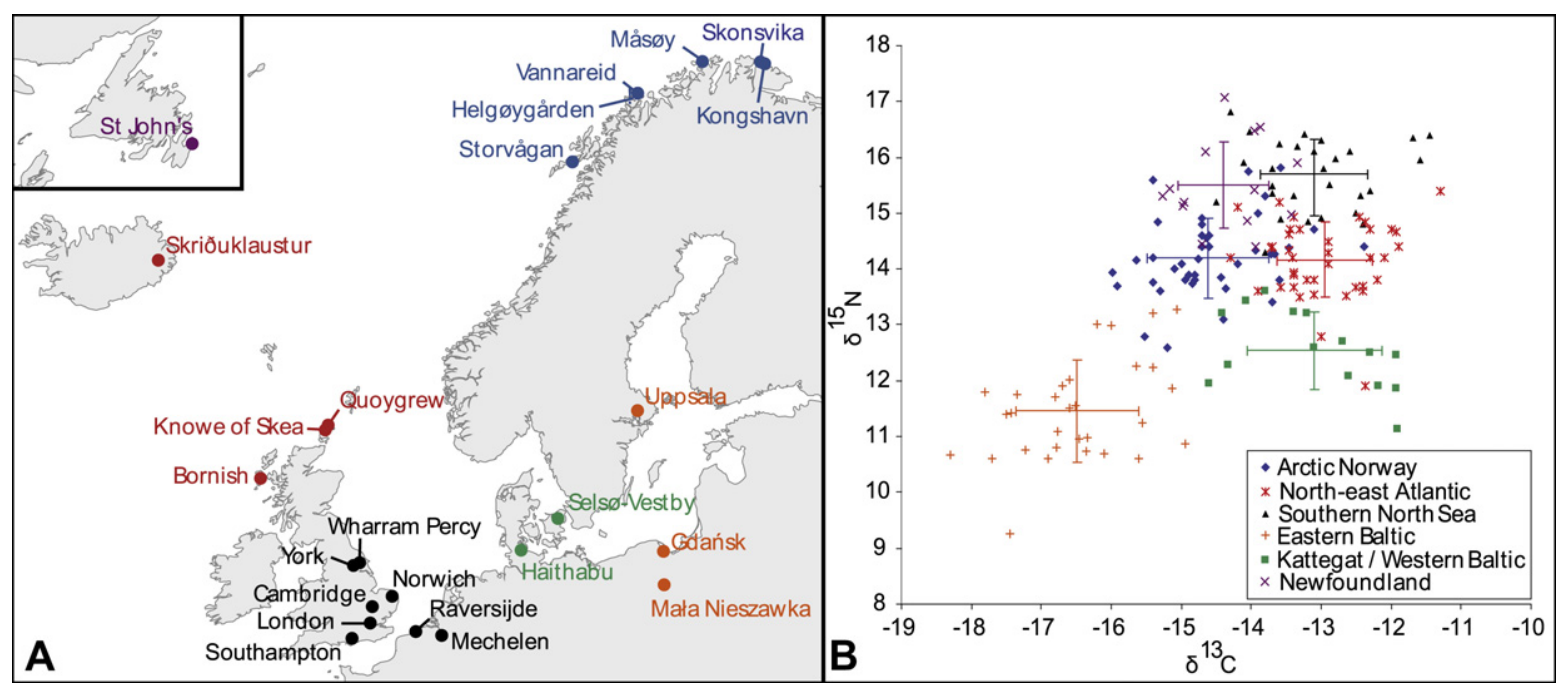

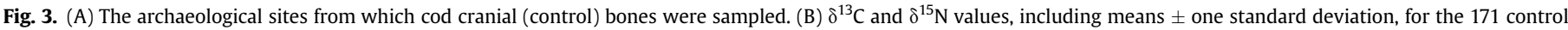
samples grouped into six analytical regions indicated by different coloured labels in $3 \mathrm{~A}$.

elements from the same fish for $\delta^{13} \mathrm{C}$ were $0.1,0.1,0.2,0.2,0.2,0.3$, 0.4 and 0.6 . The equivalent ranges for $\delta^{15} \mathrm{~N}$ were $0.2,0.2,0.3,0.4$, $0.4,0.4,0.6$ and 1.0 .

\subsection{Laboratory methods}

Cod bones greater than $1 \mathrm{~g}$ in mass were sawn in two, with one subsample archived for further study. For the second subsample (or whole specimen if under $1 \mathrm{~g}$ ), a complete cross-section (totalling $100-200 \mathrm{mg}$ ) of each bone was then processed for stable isotope analysis. Bone collagen was extracted following standard procedures outlined by Richards and Hedges (1999), with the addition of an ultrafiltration step for archaeological samples (Brown et al., 1988). Whole bone samples were demineralised in $0.5 \mathrm{M}$ aqueous $\mathrm{HCl}$ at $4{ }^{\circ} \mathrm{C}$ for $2-5$ days until demineralised, and then gelatinised at $70{ }^{\circ} \mathrm{C}$ for $48 \mathrm{~h}$, and the resulting solution filtered through a 5-8 $\mu \mathrm{m}$ filter. For the modern samples (used only to study intra-skeletal variability), the gelatinised solution was then lyophilised for $48 \mathrm{~h}$. For the archaeological samples, the gelatinised solution was ultrafiltered through a $30 \mathrm{kDa}$ filter, and then the $>30 \mathrm{kDa}$ fraction was lyophilised for $48 \mathrm{~h}$. The resultant 'collagen' was analysed in duplicate or triplicate using continuous flow isotope-ratio-monitoring mass spectrometry: a ThermoFinnigan Flash EA coupled to a Delta Plus XP mass spectrometer at the Department of Human Evolution, Max Planck Institute for Evolutionary Anthropology, Leipzig, Germany for the archaeological samples, and a Costech EA coupled to a Delta V mass spectrometer at the Godwin Laboratory, Department of Earth Sciences, University of Cambridge, for the modern samples. The $\delta^{13} \mathrm{C}$ values are reported relative to the V-PDB scale, and $\delta^{15} \mathrm{~N}$ values relative to the AIR scale. Errors on both the $\delta^{13} \mathrm{C}$ and $\delta^{15} \mathrm{~N}$ measurements are less than $0.2 \%$. Amounts of carbon and nitrogen in the collagen extract were measured, and we only report isotope values from those samples with acceptable atomic C:N ratios, defined as between 2.9 and 3.6 (DeNiro, 1985).

\section{Results}

The resulting control data - from cranial bones - show that cod from within particular regions of ocean and sea share similar isotopic values, yet there are clear differences between regions (Fig. 3, see Appendix 1 for the data set). It is therefore possible, within meaningful limits of probability, to use the $\delta^{13} \mathrm{C}$ and $\delta^{15} \mathrm{~N}$ control data to attribute individual archaeological cod bones to the regions considered (having ruled out systematic variability by skeletal element, size and time). We attribute the target bones to probable source using discriminant function analysis (DFA), the utility of which can be evaluated by considering how successful the method is at reclassifying the original data. Treating all six regions as separate sources the reclassification success rates range from $61 \%$ to $93 \%$ (Table 1 ). However, by combining the north-east Atlantic and Arctic Norwegian regions they increase to between $73 \%$ and $93 \%$. Grouping the data in this way is appropriate because historical sources indicate that dried cod produced in both Norway and the Scandinavian colonies of the north-east Atlantic (particularly Iceland) were traded via the port of Bergen during the Middle Ages (Starkey et al., 2009). For the consumers, these catches thus all represented the same product.

We take the cautious view that cod from the north-west Atlantic are unlikely to have been traded to Europe before the transatlantic expedition of Zuan Caboto ('John Cabot') in 1497 (cf. McGhee, 2003). Thus DFA has been performed both excluding and including the control data from Newfoundland - for applicability to

Table 1

Discriminant function analysis reclassification success rates for the archaeological control samples of cod bone.

\begin{tabular}{|c|c|c|c|c|c|c|c|}
\hline \multirow[t]{2}{*}{ Regions (All separate) } & \multicolumn{4}{|c|}{$\begin{array}{l}\text { Excluding } \\
\text { Newfoundland }\end{array}$} & \multicolumn{3}{|c|}{$\begin{array}{l}\text { Including } \\
\text { Newfoundland }\end{array}$} \\
\hline & $\mathrm{n}$ & \multicolumn{2}{|c|}{ Correct } & $\%$ & $\mathrm{n}$ & Correct & $\%$ \\
\hline Arctic Norway & 41 & \multicolumn{2}{|c|}{29} & 71 & 41 & 25 & 61 \\
\hline North-east Atlantic & 40 & \multicolumn{2}{|c|}{32} & 80 & 40 & 32 & 80 \\
\hline Southern North Sea & 30 & \multicolumn{2}{|c|}{24} & 80 & 30 & 21 & 70 \\
\hline Eastern Baltic & 30 & \multicolumn{2}{|c|}{28} & 93 & 30 & 28 & 93 \\
\hline Kattegat/Western Baltic & 15 & \multicolumn{2}{|c|}{12} & 80 & 15 & 12 & 80 \\
\hline Newfoundland & & & & & 15 & 10 & 67 \\
\hline Overall & 156 & 12 & & 80 & 171 & 128 & 75 \\
\hline \multirow{2}{*}{\multicolumn{2}{|c|}{ Regions (the 'North' Combined) }} & \multicolumn{3}{|c|}{$\begin{array}{l}\text { Excluding } \\
\text { Newfoundland }\end{array}$} & \multicolumn{3}{|c|}{$\begin{array}{l}\text { Including } \\
\text { Newfoundland }\end{array}$} \\
\hline & & $\mathrm{n}$ & Correc & $\%$ & $\mathrm{n}$ & Correct & $\%$ \\
\hline \multicolumn{2}{|c|}{ Arctic Norway and NE Atlantic } & 81 & 66 & 0 & 81 & 62 & 77 \\
\hline \multicolumn{2}{|l|}{ Southern North Sea } & 30 & 27 & 9 & 30 & 23 & 77 \\
\hline \multicolumn{2}{|l|}{ Eastern Baltic } & 30 & 28 & 9 & 30 & 28 & 93 \\
\hline \multirow{2}{*}{\multicolumn{2}{|c|}{$\begin{array}{l}\text { Kattegat/Western Baltic } \\
\text { Newfoundland }\end{array}$}} & 15 & 12 & 8 & 15 & 12 & 80 \\
\hline & & & & & 15 & 11 & 73 \\
\hline \multicolumn{2}{|l|}{ Overall } & 156 & 133 & 8 & 171 & 136 & 80 \\
\hline
\end{tabular}


earlier and later archaeological case studies respectively. Without Newfoundland, the DFA reclassification success rates range from $80 \%$ to $93 \%$ when the north-east Atlantic and Arctic Norway are combined. Overall the success rates are high. This result makes ecological sense given that there are established relationships between the $\delta^{13} \mathrm{C}$ and $\delta^{15} \mathrm{~N}$ values of fish tissues and environment, diet and trophic level - which vary from region to region (Fredriksen, 2003; Jennings and Warr, 2003; Sweeting et al., 2007; Weidman and Millner, 2000).

Turning to the second step of the study, because target bones could be from either local catches or long-range transport, differences in the relative abundance of local and imported fish can be evaluated by comparing their probable sources based on DFA of the $\delta^{13} \mathrm{C}$ and $\delta^{15} \mathrm{~N}$ data. The analysed bones include the earliest known finds of cod from medieval settlements such as York, Flixborough, Norwich, London, Southampton, Ghent and Mechelen - plus (within the limits of available samples) subsequent time series ending in the 15th-16th centuries for England and the 17th-18th centuries for Flanders. Following the conservative strategy noted above, the north-west Atlantic (Newfoundland) is only included as a potential source for DFA of samples dating from the 15th to 16th centuries and later.

Details of each target specimen, including probabilities of group membership based on DFA, are provided in Appendix 2. Like all archaeological characterisation studies, the attributions to source are not absolute. Not all possible fishing regions are represented in the control data, the limited number of control samples (an unavoidable characteristic of archaeology) is unlikely to represent fully the variability within each region and there is some overlap in the $\delta^{13} \mathrm{C}$ and $\delta^{15} \mathrm{~N}$ values of the data from each potential source. Nevertheless, the method can serve as a guide to when, where and in what proportions (vis-à-vis local catches) cod transported from distant waters first appeared in settlements around the southern North Sea.

Fig. 4 summarises the DFA results for the target data from London and other towns and villages in England and Flanders. It shows that the marine fishing revolution at the turn of the first and second millennia AD (Barrett et al., 2004a) was predominantly the result of local fishing - rather than the introduction of long-range trade goods. If this conclusion is true for cod it is reasonable to believe that the bones of other gadids, herring and flatfish found in archaeological remains dated to this time (Barrett et al., 2004b; Ervynck et al., 2004) were also from local catches in the southern North Sea. The 10th-11th century increase in sea fishing therefore seems to derive predominantly from the intensification of local (demand-led) production rather than changes in distant supply. Based on our DFA analyses, cod of northern origin may occasionally have been imported to towns such as York and London in the

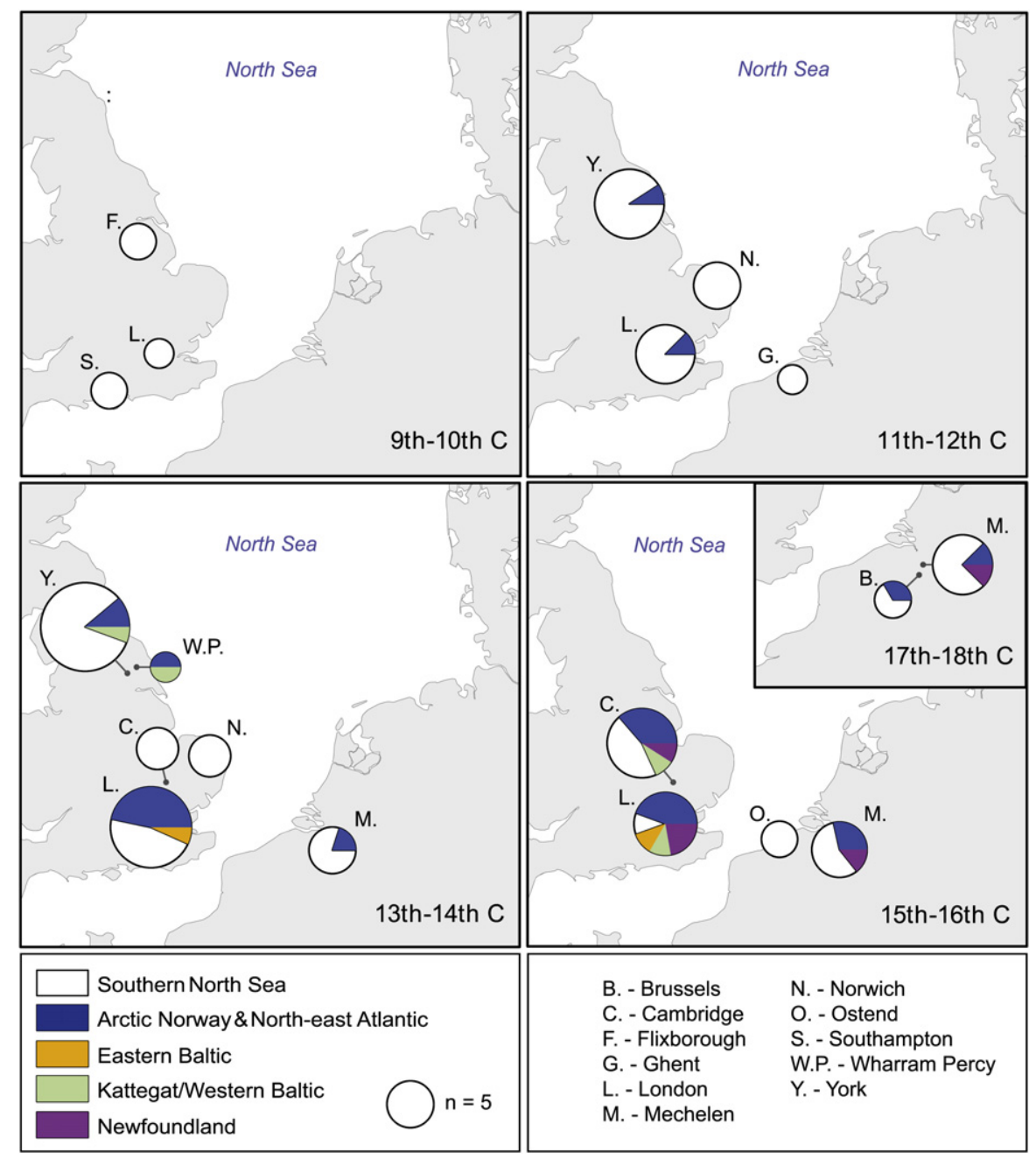

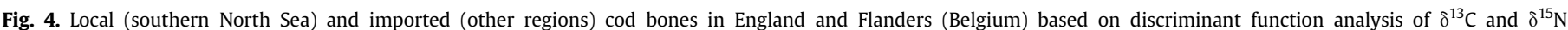

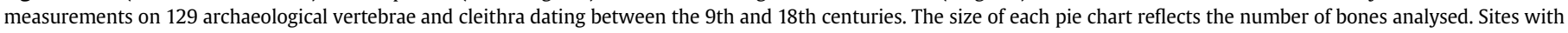
only one successful analysis are omitted for clarity. 

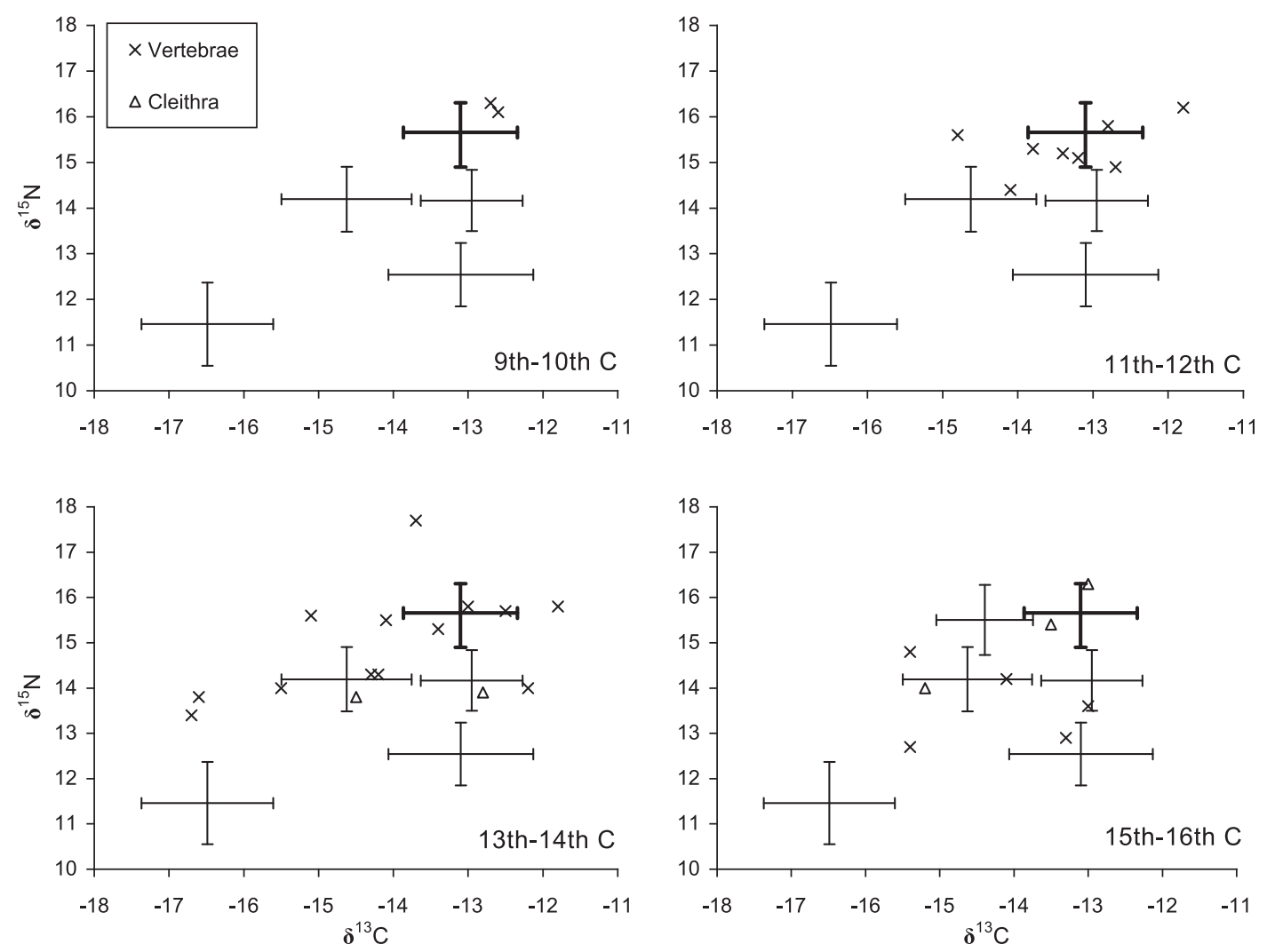

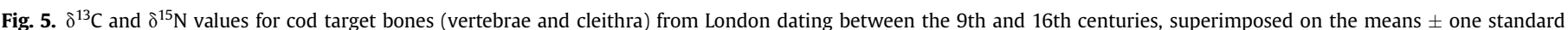

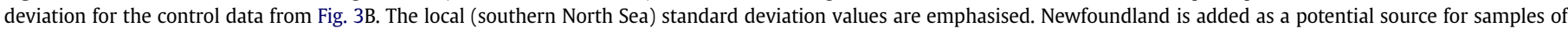
15 th-16th century date.

11th-12th centuries - consistent with previous results from a pilot study of the Viking Age town of Haithabu in the Baltic Sea region (Barrett et al., 2008). This trade may have been of importance to northern producers, but was probably a 'drop in the bucket' for consumers in the southern North Sea region. Very few of the pre13th-century target bones from England and Flanders have been attributed to a northern source (one of 12 specimens from York and one of 10 specimens from London).

By the 13th-14th centuries, conversely, more than half of the cod specimens from London are attributed to a source beyond the southern North Sea. Most are probably from very distant waters the north-east Atlantic or Arctic Norway. The single specimen attributed to the eastern Baltic could be a statistical outlier, but preserved cod were produced in the region (Jonsson, 1986) and there was maritime traffic between England and eastern Europe at this time (Lloyd, 1991). Other settlements show a less profound draw on distant resources, still relying predominantly on North Sea fishing.

In the $15^{\text {th }}$ to $16^{\text {th }}$ centuries, the trend towards more imports continues. Almost all of the specimens from London are attributed to distant sources and Cambridge and Mechelen also yield higher proportions of imported cod bones than in previous centuries. The north-east Atlantic and/or Arctic Norway remain the most common sources, but some of the bones may also be from the north-west Atlantic and the Baltic Sea. In the 17th and 18th centuries, for which only Flemish samples were available, a mix of distant and local North Sea sources remains evident.

The introduction of prepared fish from non-local sources can also be summarised in a less precise way, without reliance on the attribution of individual specimens to a probable source and the level of uncertainty this procedure necessarily entails. Fig. 5 plots the $\delta^{13} \mathrm{C}$ and $\delta^{15} \mathrm{~N}$ results for target bones from 9th to 16th century London (the best time series) against the means \pm one standard deviation of the control data from each potential source region. Comparing this graph with Fig. 3, it is clear that the London targets differ from the southern North Sea controls (which include cranial bones from London) in having both greater dispersion and differing values. The higher variation suggests that the vertebrae and cleithra derive from a wider range of sources than the cranial elements (indicating the presence of preserved fish transported from multiple non-local fishing grounds). Moreover, although some target specimens match local southern North Sea isotope values, many instead match (within one or two standard deviations of the control data means) northern regions known to have exported dried cod. Through time, the trends towards greater dispersion and different isotope values (vis-à-vis the southern North Sea control data) first become clear in the 13th-14th centuries.

\section{Discussion}

Our results suggest that the revolution in sea fishing at the turn of the first and second millennia $\mathrm{AD}$ resulted from a demand-driven intensification of local fishing rather than a supply-driven introduction of long-range trade goods. But what caused this change in demand for sea fish? The insufficiency or reduction of freshwater fish stocks, indicated by a concurrent decline in the relative importance of freshwater species in towns, must have played a role (Barrett et al., 2004a; Hoffmann, 1996; Van Neer and Ervynck, 2010). However, freshwater fish (increasingly cultivated in ponds) did continue to be available to the wealthy and in the countryside (Dyer, 1988; Van Neer and Ervynck, 2010), suggesting that their limited availability alone is unlikely to have driven fishermen to the 
sea. Christian dietary practises (encouraging the consumption of fish during Lent and other fast days) must also have contributed to the sea fishing revolution, but are unlikely to be its primary cause because they were variable through time, by region and in different social groups (Barrett et al., 2004a; Ervynck, 1997; Woolgar, 2000).

A demographic imperative - from increasing numbers of urban consumers facing the need for new sources of inexpensive and easily preserved protein - may thus also be significant. Moreover, its impact on sea fishing continued to escalate. Already by the 13th-14th centuries the appetite of growing populations in urban centres like London became sufficiently strong that local fishing in the southern North Sea could no longer supply the demand. Marine fisheries thus began to 'globalise', with fish initially traded over long distances (from Arctic Norway, Iceland and/or the Northern Isles of Scotland to London via Bergen, for example) and then sought directly by fishermen from North Sea ports who travelled to increasingly distant waters. English boats were fishing off Iceland by the 1400 s before moving on to the coast of North America in subsequent centuries (Hoffmann, 2002).

These conclusions illuminate the origins and development of the medieval sea fishing revolution. They also have implications for the chronology and magnitude of medieval urban expansion. Populous towns must have emerged early (to influence the rise of sea fishing in the 10th-11th centuries) and, in the case of London at least, grown quickly (to exceed the capacity of regional fish supplies by the 13th-14th centuries). Following this reasoning the continuing growth of demand in the 15th-16th centuries may reflect the increasing concentration of population in towns after the demographic crash of the 14th century (cf. Epstein, 2009). Concurrently, our findings increase the likelihood that medieval urban expansion impacted both freshwater and marine ecosystems - the start of an on-going process (Hoffmann, 2002; Jackson et al., 2001; Roberts, 2007).

\section{Acknowledgements}

We thank the Leverhulme Trust, the History of Marine Animal Populations project (funded by the Alfred P. Sloan Foundation) and the McDonald Institute for Archaeological Research for financial support. The contribution of Wim Van Neer results in part from the Interuniversity Attraction Poles Programme - Belgian Science Policy. Stefanie Boesel and Annette Weiske assisted with stable isotope analysis of the archaeological material. Catherine Kneale, Mike Hall and James Rolfe assisted with analysis of the modern samples. The many organisations and individuals who helped source archaeological cod bones are too numerous to mention, but the London Archaeological Archive and Research Centre, Museum of London Archaeology, NAU Archaeology, Norfolk Museums and Archaeology Service and York Archaeological Trust deserve special thanks.

\section{Appendix. Supplementary data}

Supplementary data related to this article can be found online at doi:10.1016/j.jas.2011.02.017

\section{References}

Bagge, O., Thurow, F., Steffensen, E., Bay, J., 1994. The Baltic Cod. Dana. 10.1. Barrett, J.H., 1997. Fish trade in Norse Orkney and Caithness: a zooarchaeological approach. Antiquity 71, 616-638.

Barrett, J.H., Nicholson, R.A., Cerón-Carrasco, R., 1999. Archaeo-ichthyological evidence for long-term socioeconomic trends in northern Scotland: 3500 BC to AD 1500. Journal of Archaeological Science 26, 353-388.

Barrett, J.H., Locker, A.M., Roberts, C.M., 2004a. The origin of intensive marine fishing in medieval Europe: the English evidence. Proceedings of the Royal Society of London B 271, 2417-2421.
Barrett, J.H., Locker, A.M., Roberts, C.M., 2004b. 'Dark age economics' revisited: the English fish bone evidence AD 600-1600. Antiquity 78, 618-636.

Barrett, J., Johnston, C., Harland, J., Van Neer, W., Ervynck, A., Makowiecki, D., Heinrich, D., Hufthammer, A.K., Enghoff, I.B., Amundsen, C., Schou Christiansen, J., Jones, A.K.G., Locker, A., 2008. Detecting the medieval cod trade: a new method and first results. Journal of Archaeological Science 35, 850-861.

Benecke, N., 1982. Zur frühmittelalterlichen Heringsfischerei im südlichen Ostseeraum - ein archäozoologischer Beitrag. Zeitschrift für Archäologie 16, 283-290.

Brown, T.A., Nelson, D.E., Vogel, J.S., Southon, J.R., 1988. Improved collagen extraction by modified Longin method. Radiocarbon 30, 171-177.

Christensen, J.T., Richardson, K., 2008. Stable isotope evidence of long-term changes in the North Sea food web structure. Marine Ecology Progress Series 368, 1-8.

Coy, J., Hamilton-Dyer, S., 2005. Meat and fish: the bone evidence. In: Gardiner, J. (Ed.), Before the Mast: Life and Death Aboard the Mary Rose. Mary Rose Trust/ Oxbow, Oxford, pp. 564-588.

DeNiro, M.J., Epstein, S., 1978. Influence of diet on the distribution of carbon isotopes in animals. Geochimica Cosmochimica Acta 42, 495-506.

DeNiro, M.J., 1985. Post-mortem preservation and alteration of in vivo bone collagen isotope ratios in relation to paleodietary reconstruction. Nature 317, 806-809.

Deutsch, B., Berth, U., 2006. Differentiation of western and eastern Baltic Sea cod stocks (Gadus morhua) by means of stable isotope ratios in muscles and otoliths. Journal of Applied Icthyology 22, 538-539.

Doney, S.C., 2010. The growing human footprint on coastal and open-ocean biogeochemistry. Science 328, 1512-1516.

Dyer, C., 1988. The consumption of freshwater fish in medieval England. British Series. In: Aston, M. (Ed.), Medieval Fish, Fisheries and Fishponds in England, vol. 182(i). British Archaeological Reports, Oxford, pp. 27-38.

Enghoff, I.B., 1999. Fishing in the Baltic region from the 5th century BC to the 16th century AD: evidence from fishbones. Archaeofauna 8, 41-85.

Enghoff, I.B., 2000. Fishing in the southern North Sea region from the 1 st to the 16 th century AD: evidence from fish bones. Archaeofauna 9, 59-132.

Epstein, S.A., 2009. An Economic and Social History of Later Medieval Europe, 1000-1500. Cambridge University Press, Cambridge.

Ervynck, A., 1997. Following the rule? Fish and meat consumption in monastic communities in Flanders (Belgium). In: De Boe, G., Verhaeghe, F. (Eds.), Environment and Subsistence in Medieval Europe: Papers of the 'Medieval Europe Brugge 1997' conference volume 9, (I.A.P. Rapporten 9, Zellik), pp 67-81.

Ervynck, A., Van Neer, W., Pieters, M., 2004. How the north was won (and lost again): historical and archaeological data on the exploitation of the North Atlantic by the Flemish fishery. In: Housely, R.A., Coles, G.M. (Eds.), Atlantic Connections and Adaptations: Economies, Environments and Subsistence in Lands Bordering the North Atlantic. Oxbow Books, Oxford, pp. 230-239.

Fredriksen, S., 2003. Food web studies in a Norwegian kelp forest based on stable isotope $\left(\delta^{13} \mathrm{C}\right.$ and $\left.\delta^{15} \mathrm{~N}\right)$ analysis. Marine Ecology Progress Series 260, 71-81.

Hannides, C.C.S., Popp, B.N., Landry, M.R., Graham, B.S., 2009. Quantification of zooplankton trophic position in the North Pacific Subtropical Gyre using stable nitrogen isotopes. Limnology and Oceanography 54 (1), 50-61.

Hansson, S., Hobbie, J.E., Elmgren, R., Larsson, U., Fry, B., Johansson, S., 1997. The stable nitrogen isotope ratio as a marker of food-web interactions and fish migration. Ecology 78, 2249-2257.

Hoffmann, R.C., 1996. Economic development and aquatic ecosystems in medieval Europe. The American Historical Review 10, 631-669.

Hoffmann, R., 2002. Carp, cods and connections: new fisheries in the medieval European economy and environment. In: Henninger-Voss, M.J. (Ed.), Animals in Human Histories: The Mirror of Nature and Culture. University of Rochester Press, Rochester, N.Y, pp. 3-55.

Holm, P., Starkey, D.J., Thor, J. (Eds.), 1996. The North Atlantic Fisheries, 1100-1976: National Perspectives on a Common Resource. The North Atlantic Fisheries History Association, Esbjerg.

Holmes, S.J., Wright, P.J., Fryer, R.J., 2008. Evidence from survey data for regional variability in cod dynamics in the North Sea and west of Scotland. ICES Journal of Marine Science 65, 206-215.

Hutchinson, W.F., van Oosterhout, C., Rogers, S.I., Carvalho, G.R., 2003. Temporal analysis of archived samples indicates marked genetic changes in declining North Sea cod (Gadus morhua). Proceedings of the Royal Society of London B 270, 2125-2132.

Jackson, J.B.C., Kirby, M.X., Berger, W.H., Bjorndal, K.A., Botsford, L.W., Bourque, B.J. Bradbury, R.H., Cooke, R., Erlandson, J., Estes, J.A., Hughes, T.P., Kidwell, S., Lange, C.B., Lenihan, H.S., Pandolfi, J.M., Peterson, C.H., Steneck, R.S., Tegner, M.J., Warner, R.R., 2001. Historical overfishing and the recent collapse of coastal ecosystems. Science 293, 629-638.

Jackson, J.B.C., 2008. Ecological extinction and evolution in the brave new ocean. Proceedings of the National Academy of Science USA 105, 11458-11465.

Jennings, S., Warr, K.J., 2003. Environmental correlates of large-scale spatial variation in the $\delta^{15} \mathrm{~N}$ of marine animals. Marine Biology 142, 1131-1140.

Jennings, S., Greenstreet, S.P.R., Hill, L., Piet, G.T., Pinnegar, J.K., Warr, K.J., 2002. Long-term trends in the trophic structure of the North Sea fish community: evidence from stable-isotope analysis, size-spectra and community metrics. Marine Biology 141, 1085-1097.

Jones, A.K.G., 1988. Provisional remarks on fish remains from archaeological deposits at York. British Series. In: Murphy, P., French, C. (Eds.), The Exploitation of Wetlands, vol. 186. British Archaeological Reports, Oxford, pp. 113-127.

Jonsson, L., 1986. Finska gäddor och Bergenfisk - ett försök att belysa Uppsalas fiskimport under medeltid och yngre Vasatid. In: Cnattingius, N., Neréus, T. (Eds.), Uppsala Stads Historia 7, Från Östra Aros till Uppsala: En samling uppsatser kring det medeltida Uppsala. Historiekomm, Uppsala, pp. 122-139. 
Kowaleski, M., 2003. The commercialization of the sea fisheries in medieval England and Wales. International Journal of Maritime History 15, 177-231.

Lloyd, T.H., 1991. England and the German Hanse 1157-1611: Study of Their Trade and Commercial Diplomacy. Cambridge University Press, Cambridge, UK.

Lõugas, L., 2008. Éditions. In: Béarez, P., Grouard, S., Clavel, B. (Eds.), Archéologie du Poisson: 30 ans d'archéo-ichtyologie au CNRS. APDCA, Antibes, pp. 27-33.

Makowiecki, D., 2008. Exploitation of early medieval aquatic environments in Poland and other Baltic Sea countries: an archaeozoological consideration. Atti Delle Settimane di Studio. Centro Italiano di Studi Sull'Alto Medioevo Spoleto 55, 253-277.

McGhee, R., 2003. Epilogue: was there continuity from Norse to post-medieval exploration of the New World? In: Barrett, J.H. (Ed.), Contact, Continuity and Collapse: The Norse Colonization of the North Atlantic. Brepols, Turnhout, pp. 239-248.

Minagawa, M., Wada, E., 1984. Stepwise enrichment of ${ }^{15} \mathrm{~N}$ along food chains: further evidence and the relation between $\delta^{15} \mathrm{~N}$ and animal age. Geochimica et Cosmochimica. Acta 48, 1135-1140.

Müldner, G.H., 2009. Investigating medieval diet and society by stable isotope analysis of human bone. In: Gilchrist, R., Reynolds, A. (Eds.), Reflections: 50 Years of Medieval Archaeology. Maney, Leeds, pp. 327-346.

Pampoulie, C., Stefánsson, M.O., Jörundsdóttir, T.D., Danilowicz, B.S., Daníelsdóttir, A.K. 2008. Recolonization history and large-scale dispersal in the open sea: the case study of the North Atlantic cod, Gadus morhua L. Biological Journal of the Linnean Society $94,315-329$.

Perdikaris, S., McGovern, T.H., 2008. Codfish and kings, seals and subsistence: norse marine resource use in the North Atlantic. In: Rick, T.C., Erlandson, J.M. (Eds.), Human Impacts on Ancient Marine Ecosystems: A Global Perspective. University of California Press, Berkeley, pp. 187-214.

Richards, M.P., Hedges, R.E.M., 1999. Stable isotope evidence for similarities in the types of marine foods used by Late Mesolithic humans at sites along the Atlantic coast of Europe. Journal of Archaeological Science 26, 717-722.

Rick, T.C., Erlandson, J.M. (Eds.), 2008. Human Impacts on Ancient Marine Ecosystems: A Global Perspective. University of California Press, Berkeley.

Roberts, C., 2007. The Unnatural History of the Sea. Island Press, Washington, DC.

Sarvas, T.H., Fevolden, S.E., 2005. Pantophysin (Pan I) locus divergence between inshore v. offshore and northern v. southern populations of Atlantic cod in the north-east Atlantic. Journal of Fish Biology 67, 444-469.
Schoeninger, M., DeNiro, M., 1984. Nitrogen and carbon isotopic composition of bone collagen from marine and terrestrial animals. Geochimica et Cosmochimica Acta 48, 625-639.

Starkey, D.J., Thór, J.T., Heidbrink, I., (Eds.), 2009. A History of the North Atlantic. Fisheries: From Early Times to the Mid-Nineteenth Century, Vol. 1. Verlag H.M. Hauschild GmbH, Bremen.

Struck, U., Emeis, K.-C., Voss, M., Christiansen, C., Kunzendorf, H., 2000. Records of southern and central Baltic Sea eutrophication in $\delta^{13} \mathrm{C}$ and $\delta^{15} \mathrm{~N}$ of sedimentary organic matter. Marine Geology 164, 157-171.

Svedäng, H., Righton, D., Jonsson, P., 2007. Migratory behaviour of Atlantic cod Gadus morhua: Natal homing is the prime stock-separating mechanism. Marine Ecology Progress. Series 345, 1-12.

Svedäng, H., André, C., Jonsson, P., Elfman, M., Limburg, K.E., 2010. Migratory behavior and otolith chemistry suggest fine-scale sub-population structure within a genetically homogenous Atlantic Cod population. Environ. Biol. Fishes 89, 383-397.

Sweeting, C.J., Barry, J., Barnes, C., Polunin, N.V.C., Jennings, S., 2007. Effects of body size and environment on diet-tissue $\delta^{15} \mathrm{~N}$ fractionation in fishes. Journal of Experimental Marine Biology and Ecology 340, 1-10.

Van Neer, W., Lõugas, L., Rijnsdorp, A.D., 1999. Reconstructing age distribution, season of capture and growth rate of fish from archaeological sites based on otoliths and vertebrae. International Journal of Osteoarchaeology 9, 116-130.

Van Neer, W., Ervynck, A., 2010. Defining 'natural' fish communities for fishery management purposes: biological, historical, and archaeological approaches. In: Bruce, S.G. (Ed.), Ecologies and Economies in Medieval and Early Modern Europe. Brill, Leiden, pp. 193-223.

Weidman, C.R., Millner, R., 2000. High-resolution stable isotope records from North Atlantic cod. Fisheries Research 46, 327-342.

Wright, P.J., Neat, F.C., Gibb, F.M. Gibb, I.M., Thordarson, H., 2006. Evidence for metapopulation structuring in cod from the west of Scotland and North Sea. Journal of Fish Biology 69, 181-199.

Woolgar, C.M., 2000. Take this penance now, and afterwards the fare will improve: seafood and late medieval diet. In: Starkey, D.J., Reid, C., Ashcroft, N. (Eds.) England's Sea Fisheries: The Commercial Sea Fisheries of England and Wales Since 1300. Chatham, London, pp. 36-44. 